\title{
COMPARATIVE ASSESSMENT OF COW'S MILK PRODUCTION AND ITS PRICES IN THE MEMBER STATES OF THE EUROPEAN UNION
}

\author{
MARCIN JÓZEF STANUCH \\ KRZYSZTOF JAN FIRLEJ
}

\begin{abstract}
The paper presents issues related to milk production in the Member States of the European Union. The conducted analysis and research cover the period from 2015 to 2019. The study evaluates milk production and milk prices and uses the linear Pearson's correlation in order to find out whether there is a correlation between milk prices in the individual European Union Member States. The research demonstrated that the market value of milk produced in Poland increases every year and that there is a strong and very strong correlation between individual milk prices in the Member States amounting to $85 \%$ of all surveyed entities.
\end{abstract}

Keywords: milk production, milk price, Pearson's correlation.

JEL codes: O47, C1, Q13.

\section{Introduction}

The market offers a wide range of sheep's, goat's, and cow's milk products. The production and consumption of cow's milk dominates not only in Poland, but also worldwide (Barłowska, Wolanciuk, Kędzierska-Matysek, and Litwińczuk, 2013). Milk is used as a raw material for products such as cheese, butter, cream, dairy drinks, which play a pivotal role in human nutrition (Kowalska, 2014). Milk consumption in various regions of the world is highly differentiated. According to the electronic scientific publication "Our World in Data" (Per capita..., 2017),

Marcin Józef Stanuch, BEng, MSc, Cracow University of Economics, Department of Organizational Development, ul. Rakowicka 27, 31-510 Cracow, Poland (stanuchm@uek.krakow.pl).

ORCID iD: 0000-0003-1431-8012.

Krzysztof Jan Firlej, PhD, DSc, ProfTit, Cracow University of Economics, Department of Organizational Development, ul. Rakowicka 27, 31-510 Kraków (firlejk@uek.krakow.pl). ORCID iD: 0000-0001-7870-046X. 
average milk consumption in Poland decreased from $192 \mathrm{~kg}$ in 2020 to $178 \mathrm{~kg}$ in 2017 per capita. In Germany, the consumption increased from 225 to $267 \mathrm{~kg}$, and in Europe from 206 to $215 \mathrm{~kg}$ in 2000 and 2017, respectively.

At the time of Poland's accession to the European Union, the prices of milk and related products rose significantly. The reason for this is a rapid growth in export of this raw material to the Member States (Seremak-Bulge and Swietlik, 2005). For many years (since 1984) the EU Member States applied the milk quota scheme due to a surplus of milk supply over demand (Szajner, 2012). The quotas were abolished in the early April 2015, which enabled unrestricted milk production. This was supposed to boost the EU competitiveness on the global market. The abolishment of milk quotas was discussed much earlier in the past, giving a reason for numerous debates and analyses (Bear-Nawrocka and Kiryluk-Dryjska, 2010). The abolishment of milk quotas in 2015 was an inspiration to analyze the current situation in the milk production sector on the domestic market and in the other EU Member States.

The purpose of this paper is to assess the correlation between the milk prices in the individual EU Member States with the use of Person's correlation coefficient and the basic statistical tools enabling substantive presentation of the current situation on the EU milk market. The assessment was based on data on milk production and prices in the EU Member States. The authors made the following hypothesis: there is a strong correlation between milk prices in the vast majority of the EU Member States.

\section{Materials and methods}

The comparative analysis used the annual data on the production and utilization of milk on farms from 2015-2019 published by Eurostat. The analysis compared also the average price of raw milk in Poland and abroad on the basis of data published by the EU Open Data Portal. The initial analysis used simple statistical tools such as arithmetic mean or growth rate. The main analysis consisted in the assessment of milk price correlation in the individual EU Member States with the use of the Pearson's linear correlation coefficient with the following formula:

$$
r=\frac{n \cdot \sum x \cdot y-\sum x \cdot \sum y}{\sqrt{\left(n \cdot \sum x^{2}-\left(\sum x\right)^{2}\right)\left(n \cdot \sum y^{2}-\left(\sum y\right)^{2}\right)}}
$$

The Paerson's correlation coefficient allows for measuring the direction and strength between two variables: $\mathrm{x}$ and $\mathrm{y}$. The values of $\mathrm{r}$ parameter fall within the range of [-1,1], where (Chok, 2010):

- Values close to -1 determine a weak correlation, in which when $x$ increases, $y$ decreases;

- Values close to 0 determine no correlation between the variables;

- Values close to 1 determine a strong correlation, whereby $x$ increases $y$ also increases. 
The analysis compared the milk production volumes in all Member States of the European Union (including Great Britain, the membership of which falls between 1 January 1973 and 31 January 2020) ${ }^{1}$.

\section{Results and discussion}

Germany is a major milk producer in the European Union. Average annual milk production from 2015-2019 exceeded 32 billion liters. The second largest producer is France with a production of more than 25 billion liters of milk per annum, followed by Great Britain with15 billion liters of milk production (Fig. 1).

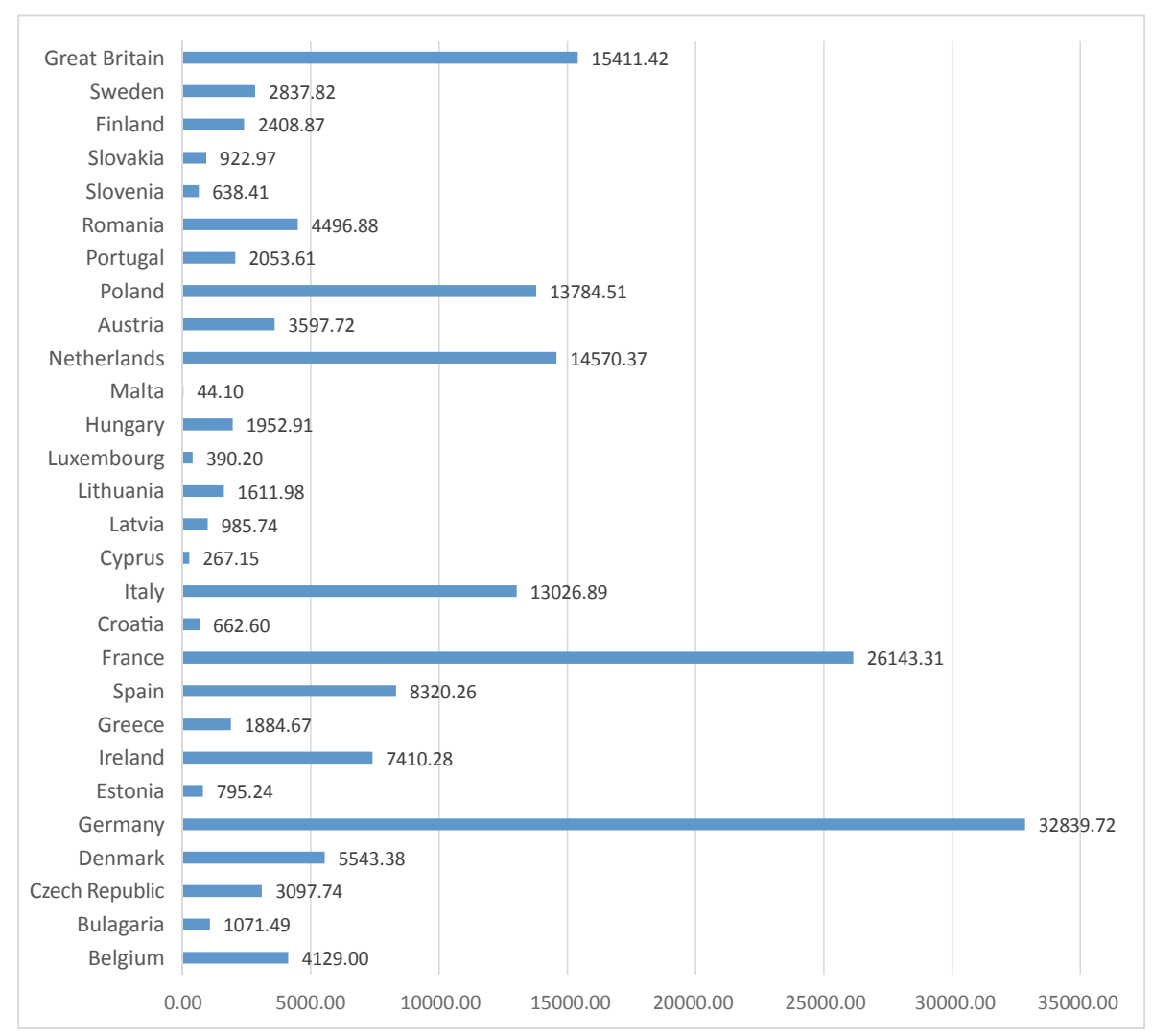

Fig. 1. Annual milk production in the individual EU Member States from 2015-2019. Source: own elaboration on the basis of data from Eurostat.

\footnotetext{
${ }^{1}$ Brexit: 1 lutego rozpoczyna się okres przejściowy między Wielka Brytania a UE. [Brexit. The Transition Period between Great Britain and the EU Starts on 1 February]. Retrieved from: www.gov.pl/ web/finanse/brexit1-lutego-rozpoczyna-sie-okres-przejsciowy-miedzy-wielka-brytania-a-ue (access date: 19 February 2021).
} 
These three countries are able to supply $43 \%$ of annual milk production in the European Union. Poland is the fifth largest milk producer, just behind the Netherlands (in 2019 the difference was 433 million liters). The average values from five years demonstrate that nearly $20 \%$ of milk production comes from the German market. The French contribution to production accounts for more than $15 \%$, while the share of the Visegrad Group (i.e. the association of Poland, the Czech Republic, Slovakia, and Hungary) is $11.56 \%$. Figure 2 presents the average value of milk production for the analyzed period divided by the percentage share of the Member States in the total EU production.

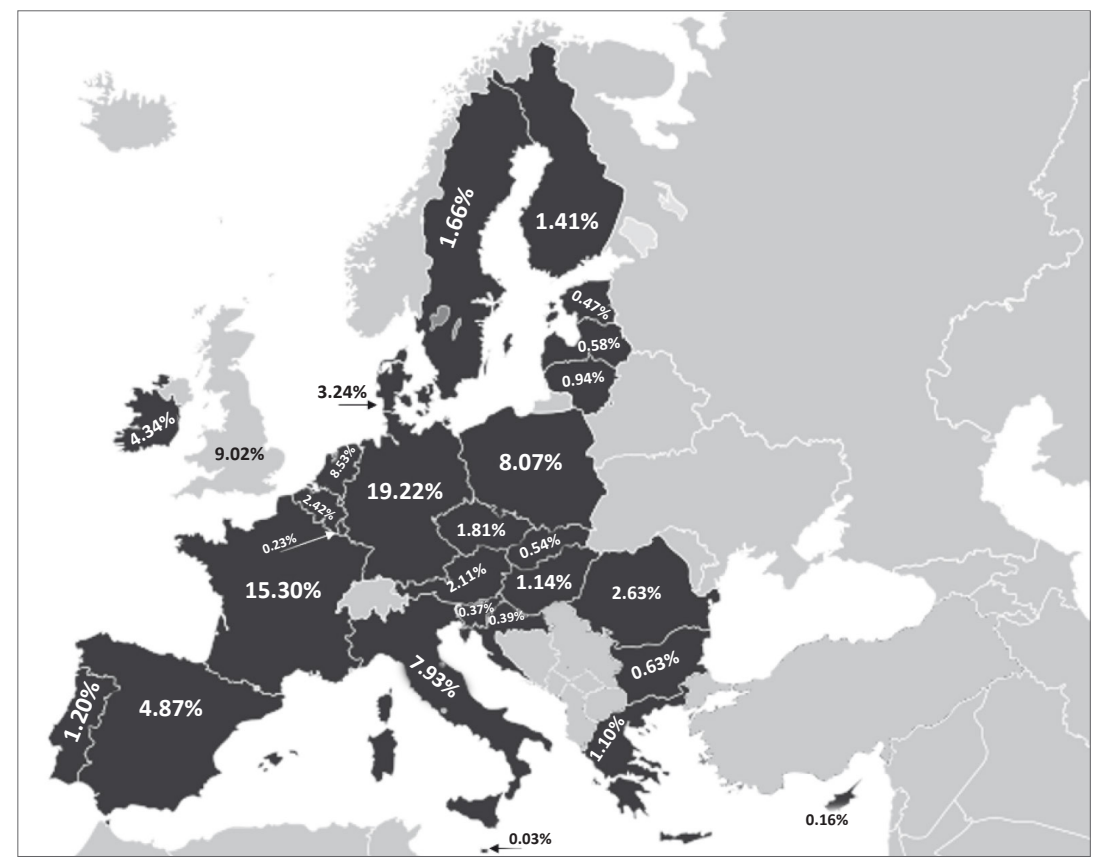

Fig. 2. The map presenting the percentage share of milk production in the Member States of the European Union from 2015-2019.

Source: own elaboration based on data from Eurostat.

The withdrawal of Great Britain from the European Union (Brexit) resulted in a change in the ranking of milk producers. Poland is ranked in fourth place with an increased share from 8.07 to $8.87 \%$ of total milk production in the EU. In the case of Germany, this value grew from 19.22 to more than $21 \%$. Total milk production in the Member States from 2015-2019 amounted to approximately 854 billion liters, of which nearly 69 billion liters were produced by Poland. In 2019, milk production in the EU was the highest and reached nearly 174 billion liters (source: Eurostat). 
Table 1

Increase/decrease in cow's milk production by the Member States (\%)

\begin{tabular}{|c|c|c|c|c|c|}
\hline \multirow{2}{*}{ Country } & \multicolumn{4}{|c|}{$\begin{array}{c}\text { Increase/decrease in cow's milk compared with the previous } \\
\text { year }(\%)\end{array}$} & \multirow{2}{*}{$\begin{array}{c}\text { Mean } \\
(\%)\end{array}$} \\
\hline & 2016 & 2017 & 2018 & 2019 & \\
\hline Belgium & 4.42 & 3.73 & 3.40 & 2.57 & 3.53 \\
\hline Bulgaria & -0.34 & -4.98 & -6.07 & -8.36 & -4.94 \\
\hline Czech Republic & 1.28 & 0.46 & 2.67 & -0.18 & 1.06 \\
\hline Denmark & 1.87 & 2.25 & 2.45 & 0.00 & 1.64 \\
\hline Germany & 0.01 & -0.22 & 1.52 & -0.02 & 0.32 \\
\hline Estonia & -0.01 & 0.94 & 0.89 & 3.00 & 1.20 \\
\hline Ireland & 4.05 & 9.12 & 4.43 & 5.28 & 5.72 \\
\hline Greece & -0.94 & -4.74 & 2.10 & 6.21 & 0.66 \\
\hline Spain & 1.40 & 1.00 & 1.41 & 1.69 & 1.37 \\
\hline France & -2.42 & -0.23 & 0.06 & -0.44 & -0.76 \\
\hline Croatia & -2.55 & -3.05 & -5.09 & -3.00 & -3.42 \\
\hline Italy & -2.91 & 2.48 & 1.14 & 1.28 & 0.50 \\
\hline Cyprus & 11.00 & 17.41 & 5.60 & 5.33 & 9.84 \\
\hline Latvia & 0.83 & 1.41 & -1.72 & -0.15 & 0.09 \\
\hline Lithuania & -6.38 & -3.50 & 0.07 & -1.32 & -2.78 \\
\hline Luxembourg & 9.66 & 2.90 & 5.24 & 3.24 & 5.26 \\
\hline Hungary & -1.17 & 2.56 & -0.97 & 0.70 & 0.28 \\
\hline Malta & 3.66 & -4.47 & -1.15 & 2.37 & 0.10 \\
\hline Netherlands & 7.55 & 0.32 & -3.01 & 3.59 & 2.12 \\
\hline Austria & -0.24 & 1.82 & 0.75 & -1.92 & 0.10 \\
\hline Poland & 0.18 & 3.21 & 3.48 & 2.34 & 2.30 \\
\hline Portugal & -4.43 & 0.01 & 0.97 & 1.56 & -0.47 \\
\hline Romania & -1.94 & -3.19 & 0.09 & -2.33 & -1.84 \\
\hline Slovenia & 2.77 & -0.22 & -2.88 & -0.88 & -0.30 \\
\hline Slovakia & -2.65 & 0.71 & -0.69 & -0.14 & -0.69 \\
\hline Finland & -0.29 & -0.98 & -0.33 & -0.98 & -0.65 \\
\hline Sweden & -2.46 & -2.58 & -1.42 & -2.01 & -2.12 \\
\hline Great Britain & -3.36 & 3.38 & 0.29 & 1.57 & 0.47 \\
\hline EU-28 & -0.10 & 1.11 & 0.86 & 0.95 & 0.70 \\
\hline
\end{tabular}

Source: own elaboration based on data from Eurostat. 
The summary of annual milk production changes presented in Table 1 uses an arithmetic mean, which is highly sensitive to the extreme values from the analyzed range. It is perfectly visible in the case of Cyprus, where the value of average production amounted to $10 \%$ and the last two years demonstrate a 5\% upward trend. It should be noted that due to the fact that the calculated values were rounded to two decimal places, data for Denmark display no visible changes in milk production in 2019 compared with the previous year. This results from rounding the figures, because the production in 2019 was slightly lower than in 2018 and the decrease in growth amounted to $0.004 \%$ (rounded to $0.00 \%$ ).

According to the presented annual fluctuations in milk production in the Member States, the following countries decrease their production each year:

- Bulgaria - average drop by $4.94 \%$;

- Croatia - drop by $3.42 \%$;

- Finland - average drop by $0.65 \%$;

- Sweden - average drop by $2.12 \%$.

This group may be extended by five other states displaying a similar trend of decreasing milk production, i.e. France, Lithuania, Romania, Slovakia, and Slovenia (to a lesser extent). The only difference is a single positive value (usually negligible) in the presented summary. Nine EU Member States records a noticeable drop in milk production on a year-by-year basis. Conversely, a regular growth in cow's milk production is being recorded in the following countries:

- Belgium - average increase by $3.53 \%$;

- Ireland - average increase by $5.72 \%$;

- Spain - regular increase by $1.37 \%$;

- Cyprus - average increase by $9.84 \%$;

- Luxembourg - average increase by $5,26 \%$;

- Poland - average annual production increase by $2.30 \%$;

Germany, as the tycoon on the EU milk market, maintains a stable production rate. Its average from the analyzed period demonstrates an annual production growth of $0.32 \%$. A $0.7 \%$ upward trend is also observable in the EU as a whole. Increase in the milk production in the EU may result from demographic changes (growing population size and therefore demand for milk products), primarily due to the migration policy in the Member States. One should note that the cattle population size (according to Eurostat data) has been gradually decreasing since 2016 in the EU-28, which may translate into higher milk yield of cows. In the 2019 communication, the Centre for Public Opinion Research pointed out the changing habits of the Poles in the context of a healthy diet, which may suggest an increased share of milk products in their diet (Jak zdrowo..., 2019).

The next step in analyzing the milk market is to compare the historical prices of raw cow's milk in the EU Member States. For this purpose, data published by the EU Open Data Portal were used. Table 2 presents the averaged annual prices for 1 ton of milk. 
Average raw milk prices in the individual EU Member States

Table 2 from 2015-2019 in EUR per 1 ton

\begin{tabular}{|c|c|c|c|c|c|}
\hline \multirow{2}{*}{ Country } & \multicolumn{5}{|c|}{ Year } \\
\hline & 2015 & 2016 & 2017 & 2018 & 2019 \\
\hline Belgium & 279.28 & 266.98 & 350.54 & 321.85 & 330.46 \\
\hline Bulgaria & 285.42 & 272.20 & 305.19 & 300.03 & 304.83 \\
\hline Czech Republic & 273.06 & 240.80 & 315.89 & 324.95 & 335.34 \\
\hline Denmark & 310.28 & 288.31 & 369.02 & 359.57 & 341.10 \\
\hline Germany & 295.75 & 273.81 & 364.08 & 347.08 & 343.47 \\
\hline Estonia & 237.13 & 237.63 & 326.78 & 307.43 & 310.02 \\
\hline Ireland & 297.43 & 280.98 & 364.18 & 350.43 & 336.92 \\
\hline Greece & 418.39 & 386.53 & 387.88 & 396.22 & 383.66 \\
\hline Spain & 301.46 & 291.19 & 309.55 & 312.30 & 318.46 \\
\hline France & 309.55 & 301.76 & 343.99 & 346.56 & 364.74 \\
\hline Croatia & 325.53 & 295.79 & 313.78 & 328.44 & 333.26 \\
\hline Italy & 346.72 & 319.89 & 370.24 & 358.66 & 393.15 \\
\hline Cyprus & 565.02 & 560.02 & 558.84 & 559.66 & 576.28 \\
\hline Latvia & 216.83 & 217.23 & 306.14 & 283.82 & 293.91 \\
\hline Lithuania & 216.69 & 216.31 & 297.57 & 283.94 & 288.78 \\
\hline Luxembourg & 298.18 & 279.96 & 354.24 & 331.89 & 342.23 \\
\hline Hungary & 259.32 & 237.96 & 304.77 & 297.48 & 309.78 \\
\hline Malta & 467.85 & 457.13 & 480.88 & 497.56 & 495.63 \\
\hline Netherlands & 306.04 & 283.75 & 379.58 & 360.42 & 356.59 \\
\hline Austria & 336.83 & 311.85 & 373.43 & 369.53 & 369.68 \\
\hline Poland & 278.28 & 259.64 & 323.65 & 319.79 & 316.91 \\
\hline Portugal & 296.63 & 280.18 & 296.82 & 307.51 & 306.48 \\
\hline Romania & 263.16 & 256.62 & 291.89 & 301.15 & 304.63 \\
\hline Slovenia & 283.33 & 252.80 & 303.20 & 303.03 & 326.17 \\
\hline Slovakia & 279.43 & 253.08 & 309.86 & 319.64 & 326.02 \\
\hline Finland & 375.94 & 370.78 & 377.20 & 379.17 & 383.25 \\
\hline Sweden & 315.40 & 306.96 & 379.43 & 346.38 & 348.23 \\
\hline Great Britain & 329.05 & 268.74 & 318.22 & 323.44 & 320.54 \\
\hline EU-28 & 305.99 & 284.33 & 348.56 & 341.12 & 345.19 \\
\hline
\end{tabular}

Source: own elaboration based on data from the EU Open Data Portal. 
In 2016, milk prices were the lowest in the entire analyzed period in vast majority of the EU Member States (excluding Cyprus). 2017 brought a significant boost in the market prices. Poland recorded a spike by approximately $25 \%$, while in Germany, which is the leading producer of milk, the prices of this raw material soared by $33 \%$. The price escalation affected mostly the inhabitants of Latvia, where it amounted to nearly $41 \%$. In Greece, the growth rate was below $0.5 \%$. One should also note that in 2017 the average price of 1 ton of milk in the European Union amounted to EUR 348.56 and was the highest in the discussed period. The main reason behind the spike was the climbing selling prices of milk products, which translated into higher buying-in prices (Agro-Telegram, 2017). In 2017, Poland recorded a significant export of milk and concentrated cream (increase by more than $18 \%$ compared with 2016 ), and of all milk products by $1.9 \%$. The boost was also observed in the prices of butter (from PLN 12/kg in May 2016 to more than PLN 22/kg in May 2017), which triggered the growth of milk prices.

Figure 3 presents the average value of the raw milk price from 2015-2019. Poland was highlighted with a different color in contrast to the other Member States. The price brackets in the EU as a whole fall between EUR 250-400. The prices usually oscillated around EUR 300.

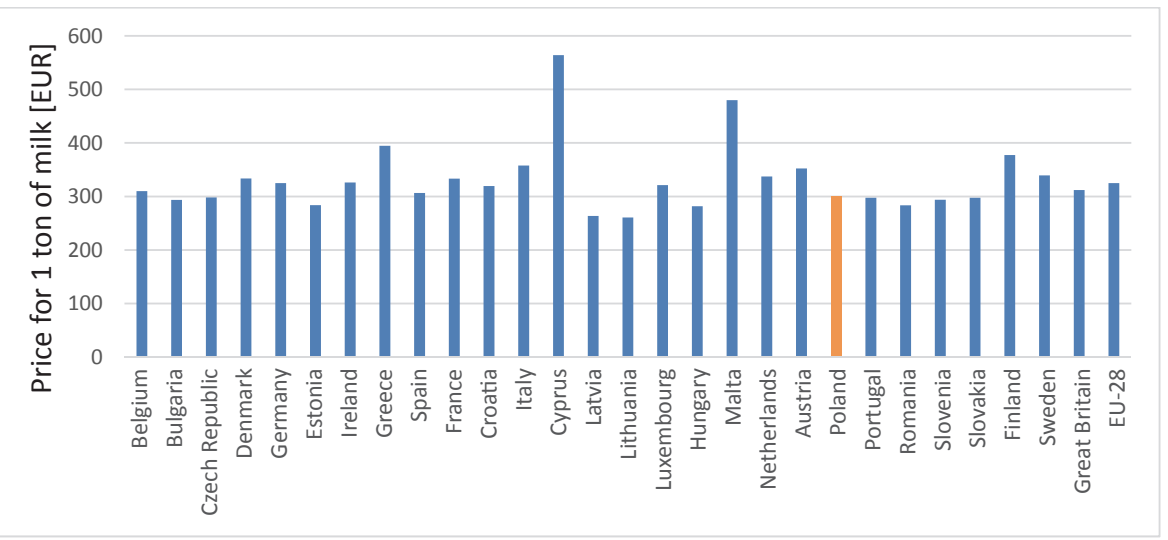

Fig. 3. Average price of 1 ton of milk from 2015-2019 in EUR.

Source: own elaboration based on data from the EU Open Data Portal.

When analyzing Figure 3, it is difficult not to notice Cyprus as the outlier, where the average price of 1 ton of milk amounted to approximately EUR 563. This price is the highest from among the Member States and exceeds the EU average by more than $70 \%$ (EUR 325). This value may result from a high supply of milk on the domestic market. In Poland, the value of 1 ton of milk amounts to nearly EUR 300, similar to the Czech Republic (298), Portugal (297), and Slovakia (297). The ranking is closed by Lithuania (260), Latvia (263), and Hungary(281). Thus, the average milk price in Poland amounts to $92 \%$ of its average value in the EU. This means that in statistical terms, the price of milk on the domestic market is lower comparing to the EU average. 
Market value of milk production in the individual EU Member States

Table 3 from 2015-2019 in EUR million

\begin{tabular}{|c|c|c|c|c|c|c|}
\hline Country & 2015 & 2016 & 2017 & 2018 & 2019 & Mean \\
\hline Belgium & $1,068.51$ & $1,066.60$ & $1,452.64$ & $1,379.13$ & $1,452.36$ & $1,283.85$ \\
\hline Bulgaria & 328.97 & 312.67 & 333.11 & 307.59 & 286.39 & 313.75 \\
\hline Czech Republic & 826.42 & 738.12 & 972.72 & $1,027.37$ & $1,058.33$ & 924.59 \\
\hline Denmark & $1,655.58$ & $1,567.16$ & $2,050.96$ & $2,047.34$ & $1,942.12$ & $1,852.63$ \\
\hline Germany & $9,666.46$ & $8,950.15$ & $11,874.28$ & $11,491.54$ & $11,369.63$ & $10,670.41$ \\
\hline Estonia & 185.75 & 186.11 & 258.35 & 245.21 & 254.68 & 226.02 \\
\hline Ireland & $1,964.37$ & $1,930.90$ & $2,730.93$ & $2,744.27$ & $2,777.83$ & $2,429.66$ \\
\hline Greece & 801.22 & 733.24 & 700.91 & 730.98 & 751.76 & 743.62 \\
\hline Spain & $2,443.34$ & $2,393.16$ & $2,569.44$ & $2,628.79$ & $2,725.90$ & $2,552.13$ \\
\hline France & $8,268.96$ & $7,865.60$ & $8,945.95$ & $9,018.31$ & $9,450.09$ & $8,709.78$ \\
\hline Croatia & 230.15 & 203.80 & 209.61 & 208.23 & 204.95 & 211.35 \\
\hline Italy & $4,524.62$ & $4,052.90$ & $4,806.93$ & $4,709.77$ & $5,228.93$ & $4,664.63$ \\
\hline Cyprus & 120.96 & 133.09 & 155.93 & 164.90 & 178.85 & 150.75 \\
\hline Latvia & 212.08 & 214.24 & 306.17 & 278.96 & 288.44 & 259.98 \\
\hline Lithuania & 376.72 & 352.08 & 467.39 & 446.31 & 447.94 & 418.09 \\
\hline Luxembourg & 103.17 & 106.22 & 138.31 & 136.37 & 145.19 & 125.85 \\
\hline Hungary & 504.80 & 457.78 & 601.30 & 581.19 & 609.46 & 550.91 \\
\hline Malta & 20.60 & 20.86 & 20.97 & 21.44 & 21.87 & 21.15 \\
\hline Netherlands & $4,218.43$ & $4,206.59$ & $5,645.54$ & $5,199.37$ & $5,328.91$ & $4,919.77$ \\
\hline Austria & $1,202.09$ & $1,110.29$ & $1,353.70$ & $1,349.58$ & $1,324.21$ & $1,267.97$ \\
\hline Poland & $3,688.06$ & $3,447.15$ & $4,434.78$ & $4,534.39$ & $4,598.81$ & $4,140.64$ \\
\hline Portugal & 627.15 & 566.14 & 599.80 & 627.41 & 635.06 & 611.11 \\
\hline Romania & $1,230.69$ & $1,176.77$ & $1,295.77$ & $1,338.10$ & $1,321.95$ & $1,272.65$ \\
\hline Slovenia & 179.58 & 164.67 & 197.07 & 191.28 & 204.06 & 187.33 \\
\hline Slovakia & 263.19 & 232.04 & 286.12 & 293.11 & 298.53 & 274.60 \\
\hline Finland & 916.08 & 900.85 & 907.45 & 909.20 & 909.97 & 908.71 \\
\hline Sweden & 936.16 & 888.71 & $1,070.23$ & 963.10 & 948.78 & 961.40 \\
\hline Great Britain & $5,086.13$ & $4,014.46$ & $4,914.22$ & $5,009.50$ & $5,042.44$ & $4,813.35$ \\
\hline EU-28 & $51,713.93$ & $48,001.77$ & $59,499.44$ & $58,729.27$ & $59,992.77$ & $55,587.43$ \\
\hline
\end{tabular}

Source: own elaboration based on data from the EU Open Data Portal and Eurostat. 
The last stage of analysis was to present the general market value of cow's milk production in the EU Member States (Table 3). The market value of produced milk in Poland grew from EUR 3.7 billion in 2015 to EUR 4.6 billion in 2019. This means an increase in value by $20 \%$ and the average value in this period at the level of EUR 4.1 billion. In the case of the production leader - Germany - the market value of milk in 2019 is estimated at EUR 11.37 billion and its growth in the analyzed period was $17.6 \%$. The lowest values were recorded for Malta, where in 2019 the value of milk production market amounted to EUR 21.15 million. The average market value of milk production from 2015-2019 for the EU as a whole was EUR 55.5 billion, while in 2019 it nearly reached EUR 60 billion.

\section{Regional approach - Poland}

The analysis also presented the differentiation of milk production in the individual voivodeships in Poland from 2015-2019. The purpose of the regional approach was to identify the regions with the most intensive milk production and their impact on the scale of national production. The necessary data were collected from the national source of information, i.e. the Local Data Bank (Statistics Poland data). Figure 4 shows the two dominating regions of milk production in Poland: the Mazowieckie Voivodeship with the average of 3 billion liters per annum and the Podlaskie Voivodeship with 2.8 billion liters. Total production volume in this regions accounts for more than $42 \%$ of national production. The Wielkopolskie Voivodeship (1.9 billion liters) comes third in the ranking, followed by the WarmińskoMazurskie, Łódzkie, and Kujawsko-Pomorskie Voivodeships with the production volume of approximately 1 billion liters. The lowest production volume was recorded in the Lubuskie (approximately 95 million liters), Zachodniopomorskie (158 million liters), and Dolnośląskie (187 million liters) Voivodeships.

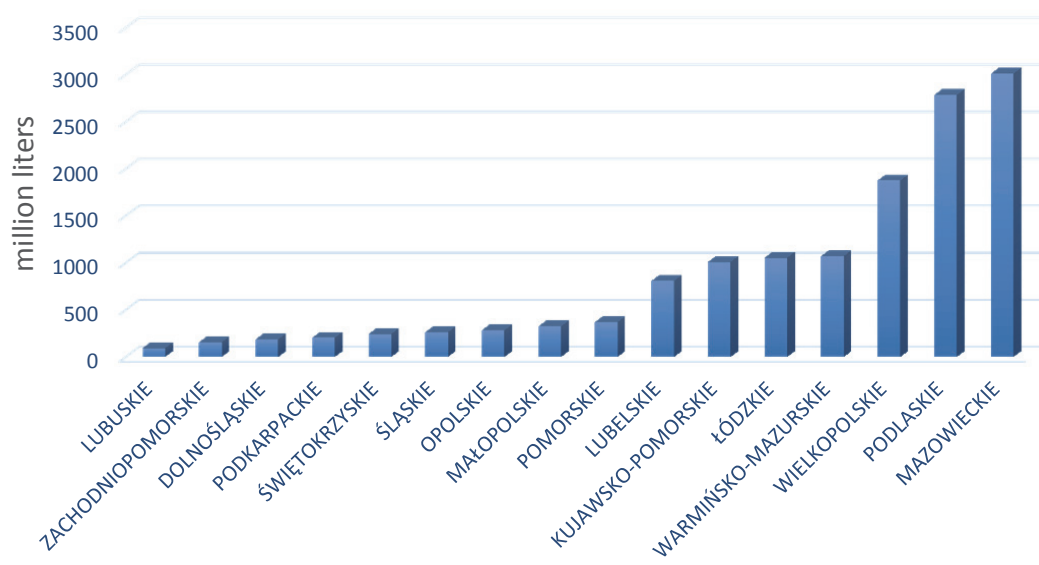

Fig. 4. Average milk production in the individual voivodeships in Poland from 2015-2019 in million liters.

Source: own elaboration based on data from the Local Data Bank. 
In the case of the Mazowieckie Voivodeship that held a dominant position in the summary, milk production from 2015-2019 increased by 18\%. Production growth by $13 \%$ was also observed in the Wielkopolskie and the Kujawsko-Pomorskie Voivodeships. A significant decline in production growth was observed in the Podkarpackie (-30\%), Świętokrzyskie (-15\%), and Małopolskie (approximately $-13 \%$ ) Voivodeships.

In this context, it is worth mentioning the trends in cow's milk yield in individual countries. The analysis is based on earlier data on milk production and cow population size (cattle aged 2 and more - dairy cows) made available by Statistics Poland. In the Opolskie Voivodeship, cow's milk yield amounted to approximately 7,330 liters per annum. The second dominant region was the Wielkopolskie Voivodeship $(7,227$ 1), followed by the Dolnośląskie Voivodeship(7,139 1). The lowest figures were recorded in the Małopolskie (4,200 1), Podkarpackie(approximately 4,800 1), and Świętokrzyskie Voivodeships (4,900 1). Annual cow's milk yield in the remaining voivodeships was slightly above 5,000 $\mathrm{l}$. The difference in production between the Opolskie and Małopolskie Voivodeships accounted for $74 \%$. Average annual cow's milk yield in the country was 6,286 liters.

\section{Pearson's correlation}

The research conducted with the use of the Pearson's correlation (Table 4) determined the level of correlation between milk prices in the individual EU countries. The research demonstrated a strong correlation between milk prices in the individual Member States in the vast majority of cases. Nearly $85 \%$ of results were classified as above 0.5 . This means that if the price of milk grows in one country, there is a high probability that this increase will be also noticeable in any other randomly selected country. Weak or moderate correlation of prices between the countries applies to approximately $14 \%$ of analyzed cases (values from -0.5 to 0.5 ). Merely $1 \%$ refers to cases in which a price increase in one country translates into a decrease in another (values below -0.5). For example: Greece-Estonia, Greece-Latvia, or Greece-Lithuania. Thus, there is a strong price correlation between the individual EU countries. The only exception is Greece, where the correlation coefficients have mainly negative values, which may demonstrate a reversed dependency comparing to the remaining Member States. Cyprus, with a weak or moderate correlation with the other countries, should be also mentioned. This country showed a strong correlation with Italy (0.64), Croatia (0.59), and Slovenia (0.58). The Italian Republic is the key trading partner of Cyprus in terms of domestic exports $(7.5 \%$ of total imports according to the Ministry of Development), which may underlie certain interrelationships. According to the business report of PKO Bank Polski (PKO Bank Polski, 2021), Croatia and Slovakia established strong relations in the area of trading in goods (export and import). Although the authors established no strong correlations of these countries in their business relations with Cyprus, certain legal conditions (e.g. tax heaven) or another random factor that affected the model result can be indicated. 
+
$\frac{0}{0}$
$\frac{\pi}{0}$

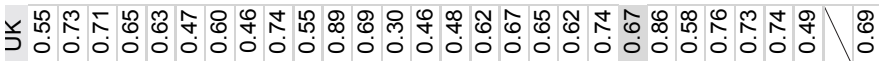

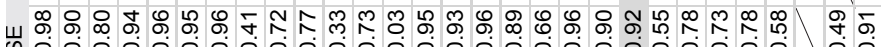

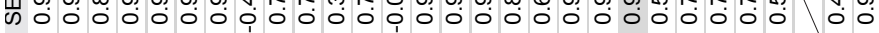

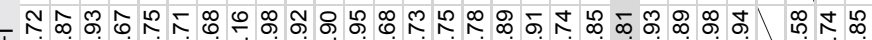

廿

๘ फ

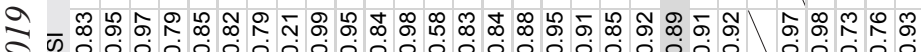
ح

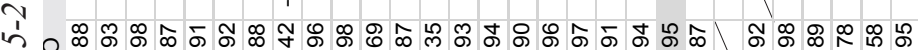
$\checkmark$ ఇ $\sim$ క

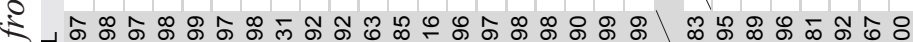

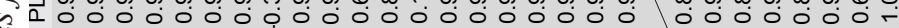
记

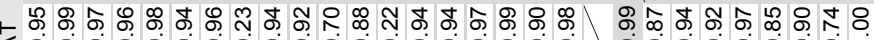

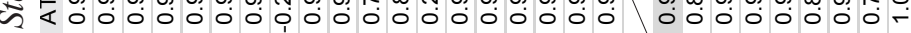
ปे z $0000-0000000000000$ 0 ஹ

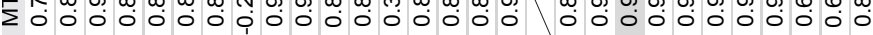
代 శ د స

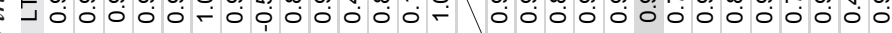

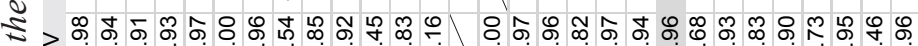

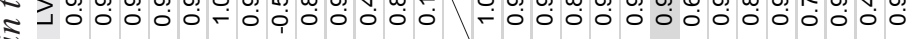
幺

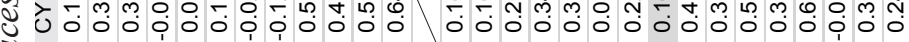

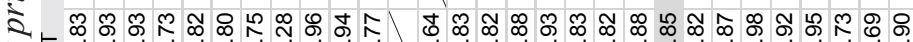

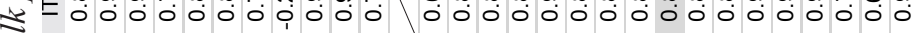

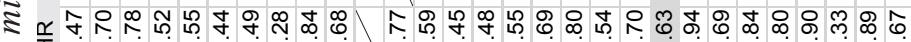

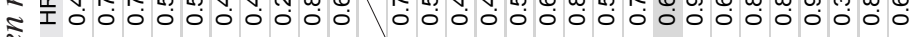
¿

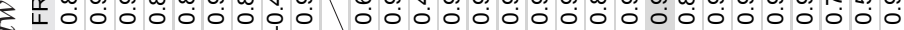
ऽ ๘

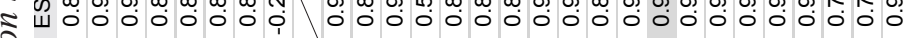
梽 U హ U Ш ڤ ప ○ ะ レ F

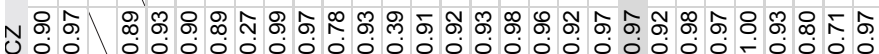

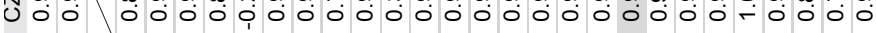

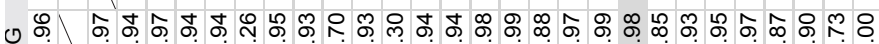

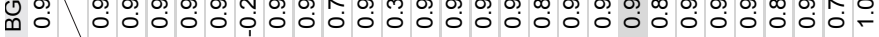
山 \&

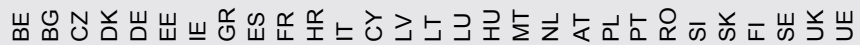

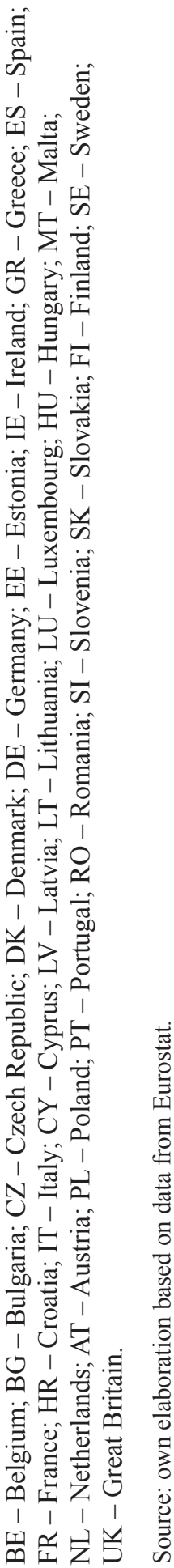


Poland demonstrates a strong price correlation with the vast majority of the EU Member States. The only exception is Greece, for which the correlation amounted to -0.31 and Cyprus with a value of 0.16. A strong correlation was recorded for Great Britain (0.67) and Croatia (0.63), while a very strong correlation was reported for the remaining group of Member States. The correlation of Poland with Germany, the Netherlands, and Austria amounted to 0.99, which proves the strong interdependence of prices. Germany and the Netherlands are the key recipients of Polish agri-food products, with a share in total export of 28.2 and $6.5 \%$, respectively (PKO, 2021). Interestingly enough, price correlation between Poland and all Member States (i.e. the overall result for the EU) amounted to 1. Such a result the same only for Austria and Bulgaria. This demonstrates the linear correlation of growth in milk prices for the above-mentioned Member States within the average value for the Community. This means that if the average milk prices in the EU increase by $5 \%$, the domestic market will also experience a growth by approximately $5 \%$.

\section{Conclusions}

The analysis determined the share of milk production in the individual EU Member States. The research on the average value of milk price (in the production aspect) in the individual Member States was also performed. This leads to the following conclusions:

1. Poland has a very strong correlation of milk prices with the EU average. This means that the increase in prices on the European market will result in a similar increase on the domestic market.

2. The market value of milk produced in Poland grows faster than in Germany, the EU leader.

3. The Podkarpackie Voivodeship recorded a decrease in milk production growth by $30 \%$, which may translate into a gradual "withdrawal" from this type of production in the region. 


\section{Literatura}

AgroTelegram (2017). Rynek mleka i produktów mleczarskich. Retrieved from: https://www. google.com/url?sa=t\&rct=j\&q=\&esrc $=$ s\&source=web\&cd=\&ved=2ahUKEwidqomJur LxAhVKvIsKHXyPDMsQFjAAegQIBhAD\&url=https\%3A\%2F\%2Fwww.aliorbank. $\mathrm{pl} \% 2 \mathrm{Fdam} \% 2 \mathrm{Fjcr} \% 3$ Afd74befc-7574-47aa-8b95-c45d50adceba\%2Frynek-mleka-produktow-mleczarskich-sierpien-2017.pdf\&usg=AOvVaw3J_QALotvb5lymD0aCX599 (access date: 29.02.2021).

Barłowska, J., Wolanciuk, A. Kędzierska-Matysek, M., Litwińczuk, Z. (2013). Wpływ sezonu produkcji na podstawowy skład chemiczny oraz zawartość makro- i mikroelementów w mleku krowim i kozim. Żywność - Nauka - Technologia - Jakość, No. 6(91), pp. 69-70.

Bear-Nawrocka, A., Kiryluk-Dryjska, E. (2010). Konsekwencje zniesienia kwot mlecznych dla polskiego rolnictwa z uwzględnieniem zróżnicowania regionalnego: wyniki symulacji modelowych. Zagadnienia Ekonomiki Rolnej, No. 2(323), pp. 62-63.

Brexit: 1 lutego rozpoczyna się okres przejściowy między Wielka Brytania a UE. Retrieved from: www.gov.pl/web/finanse/brexit-1-lutego-rozpoczyna-sie-okres-przejsciowy-miedzy-wielka-brytania-a-ue (access date: 19.02.2021).

Chok, N.S. (2010). Pearson's Versus Spearman's and Kendall's Correlation Coefficients for Continous Data. Mester's Thesis, University of Pittsburgh. Retrieved from: http://d-scholarship.pitt.edu/id/eprint/8056/1/Chokns_etd2010.pdf.

EU milk prices (2021). Retrieved from: Official website of the European Union: https://data. europa.eu/euodp/pl/data/dataset/eu-milk-market-observatory-eu-historical-prices.

Jak zdrowo odżywiają się Polacy? (2019). Retrieved from: Centrum Badania Opinii Społecznej: https://www.cbos.pl/SPISKOM.POL/2019/K_106_19.PDF.

Kowalska,A. (2014). Mleko i przetwory mleczne w diecie studentów Uniwersytetu Ekonomicznego we Wrocławiu. Roczniki Naukowe SERiA, Vol. XVI, Issue. 1, pp. 111.

Ministerstwo Rozwoju (2020). Cypr, Informacja o sytuacji gospodarczej i stosunkach gospodarczych z Polską.

Per capita milk consumption (2017), Our Word in Data. Retrieved from: https://ourworldindata. org/grapher/per-capita-milk-consumption (access date: 25.02.2021).

PKO Bank Polski (2021). Kwartalnik Eksportera. Globalny handel nie zważa na waskie gardło $i$ zatory $w$ transporcie. Retrieved from: Wspieramy Eksport: https://wspieramyeksport.pl/api/ public/files/2209/PKO-KEX-21q2_v1.pdf.

Podział kwot mlecznych w sezonie 2014/2015. Gospodarz - Twój Portal Rolniczy. Retrieved from: https://www.gospodarz.pl/aktualnosci/bydlo-i-mleko/ke-opublikowala-ostateczny-podzial-kwot-mlecznych-w-sezonie-20142015.html (access date: 25.02.2021).

Population on 1 January by broad age group and sex, Officialwebsite of theEuropeanUnion. Retrieved from: https://ec.europa.eu/eurostat/databrowser/view/demo_pjanbroad/default/table?lang=en (access date: 25.02.2021).

Portal Otwartych Danych UE. Official website of the European Union. Retrieved from: https:// data.europa.eu/euodp/pl/about (access date: 29.02.2021).

Production and utilization of milk on the farm - annual data. Official website of the European Union Retrieved from: https://appsso.eurostat.ec.europa.eu/nui/show.do?dataset=apro_mk_farm \&lang=en, (access date: 29.02.2021).

Seremak-Bulge, J., Świetlik, K. (2005). Zmiana rynkowych uwarunkowań produkcji i przetwórstwa mleka. In: J. Seremak-Bulge, Rozwój rynku mleczarskiego i zmiany jego funkcjonowania w latach 1990-2005 (pp. 9-53). Program Wieloletni 2005-2009, No. 21. Warszawa: IERiGŻ-PIB. 
Słowenia Analiza Międzynarodowa, Departament Analiz Ekonomicznych. Retrieved from: https:// wspieramyeksport.pl/znajdz-rynki-eksportowe/si/s\%C5\%82owenia (access date: 25.05.2021).

Statistics Poland (2021). Produkcja mleka krowiego. Retrieved from: https://bdl.stat.gov.pl/ BDL/dane/podgrup/temat (access date: 29.02.2021).

Szajner, P. (2012). Ocena wpływu likwidacji kwot mlecznych na konkurencyjność polskiego mleczarstwa w kontekście teorii ekonomii. Zeszyty Naukowe $S G G W w$ Warszawie Problemy Rolnictwa Światowego, Vol. 12(27), Issue 2, pp. 104-105. 


\title{
OCENA PORÓWNAWCZA PRODUKCJI I CEN MLEKA KROWIEGO W PAŃSTWACH CZŁONKOWSKICH \\ UNII EUROPEJSKIEJ
}

\begin{abstract}
Abstrakt
$W$ artykule przedstawiono zagadnienia zwiazane z produkcja mleka $w$ państwach członkowskich Unii Europejskiej. Przeprowadzona analiza oraz badania dotycza okresu od 2015 do 2019 roku. Dokonano oceny produkcji i cen mleka oraz przeprowadzono badanie korelacji liniowej Pearsona w celu uzyskania odpowiedzi, czy istnieje wspótzależność cen mleka w poszczególnych krajach Unii Europejskiej. Badania dowiodly, że wartość rynkowa wyprodukowanego mleka w Polsce corocznie wzrasta, oraz że istnieje silna oraz bardzo silna zależność między poszczególnymi cenami mleka w państwach członkowskich, wynosząca $85 \%$ wszystkich badanych podmiotów.
\end{abstract}

Słowa kluczowe: produkcja mleka, cena mleka, korelacja Pearsona.

Submission date: 17.03.2021.

Final revision date: 20.04.2021.

Acceptance date: 08.06.2021.

Unless stated otherwise all the materials on the website are available under the Creative Commons Attribution 4.0 International license.

Some rights reserved to the Institute of Agricultural and Food Economics - National Research Institute.

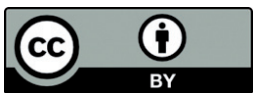

